\title{
Al-Biqā̄ī’s Self-Reflection: A Preliminary Study of the Autobiographical in His 'Unwān al-Zamān
}

\author{
Kenneth Goudie
}

When discussing the life of Burhān al-Dīn al-Biqā'ì (8o9-85/1406-8o), a 15thcentury Quran exegete and historian, modern scholarship has primarily focused on the three controversies in which he became embroiled and which defined the downward trajectory of his later career from 868/1464 until his death in 885/148o. These three controversies were, successively, on the use of the Bible in tafsīr, the poetry of Ibn al-Fāriḍ, and the theodicy of al-Ghazālī. ${ }^{1}$ The sole exception to this trend has been the work of Li Guo, who has discussed the role of the autobiographical in al-Biqā'ī's chronicle, the Iz̧hār al-'așr li-asrār ahl al-'așr. ${ }^{2}$ By analyzing al-Biqā'i’'s treatment of three episodes in his life-his infamous divorce case, the harem politics of his concubines, and the premature deaths of his children-Guo provides ample insight into how al-Biqāî̀ integrated elements from his own life into his salvation history project.

Nevertheless, however interesting and insightful Guo's discussion is - both in terms of what it reveals about al-Biqāē's character and his approach to history writing - all three of these episodes date from after al-Biqā̄ī's establish-

* This chapter has been finalized within the context of the project "The Mamlukisation of the Mamluk Sultanate II: Historiography, political order and state formation in $15^{\text {th }}$ century Egypt and Syria" (University of Gent, 2017-21); this project has received funding from the European Research Council (ERC) under the European Union's Horizon 2020 research and innovation programme (Consolidator Grant agreement No 681510). A draft version of this article was presented on July 7, 2018 at the Fifth Conference of the School of Mamluk Studies at Ghent University. My thanks go to the Süleymaniye Yazma Eser Library for providing digital images of MS Köprülü 1119 and to the Maulana Azad Library for providing digital images of MS 'Arabiyya akhbār 40.

1 For the Bible controversy, see in particular Saleh, Fifteenth. For an edition of al-Biqāî’s treatise in defense of the Bible, see Ibid. Defense. For the controversy over the poetry of Ibn al-Farī, see Homerin, Arab 55-75. For al-Biqā̄î's involvement in the debate on the best possible world, see Ormsby, Theodicy $135^{-6}$.

2 Guo, Tales. For a more general study of the Iz̧hār al-'așr, see Guo's Al-Biqāî̀'s. For the edition, see al-Biqā̄ī, İ̧hār al-'aṣr. 
ment in Cairo. That is to say, Guo's focus is still primarily on al-Biqāī as a more mature member of the Cairene intellectual elite. The point at which Guo begins his examination of al-Biqāî̀s life is essentially the point at which al-Biqāìi was at his most successful. Al-Biqāī path to this success is relatively unexplored. His early life has only been discussed with brevity and is included more to provide the necessary context for discussion of his later life than as an object of study in its own right. This is, of course, a result of how our sources, in general, conceive biography. Unlike modern biographers, who focus on the dynamic and contingent development of character, our sources understand character as determined and fixed and are more interested in the ways in which their subject was exemplary or prototypical. Consequently, exploring the formative years of their subjects was less pressing.

In the case of al-Biqāî̀, however, we are in the fortunate position of having an earlier autobiographical notice, which is contained within his Unwān alzamān bi-taräjim al-shuyūkh wa-l-aqrān. The first part of this notice was written in $841 / 1437$ (that is, the year before he received his first appointments as Sultan Jaqmaq's hadīth teacher and as the mufassir at the Zāhir Mosque) when he was 32 years old and covers his life up until that point. To this, al-Biqâ̄i added subsequent notes concerning the years 837/1433-4, 842/1438-9, and 845/14412. This notice has been discussed before. Muhammad al-Ișlāḥi, the editor of a medieval handlist of al-Biqāî's works, used it as the basis of his introductory biography of al-Biqā̄i ${ }^{3}{ }^{3}$ That being said, al-Ișlāhī's discussion of it is descriptive rather than analytical and is essentially a quotation of the notice with interspersed editorial remarks. Otherwise, Walid Saleh is the only scholar to discuss this notice, but he uses it only to make minor corrections to Guo's biography of al-Biqā̄ì, upon which he based his own brief biography of al-Biqā̄i ${ }^{4}$

When discussing Arabic autobiography, the main point of reference remains the 2001 volume entitled Interpreting the self: Autobiography in the Arabic literary tradition, edited by Dwight F. Reynolds. ${ }^{5}$ This volume, which consists of an analysis of roughly 140 Arabic autobiographical texts written between the 9th and 19th centuries alongside partial translations of 13 autobiographies, argues convincingly both against the supposed rarity of Arabic autobiography and for the vitality of the tradition.

Rather than approaching the Arabic tradition through the lens of the Western tradition, Interpreting the self analyzes the texts on their own merits and highlights four recurring features that played an important role in their authors'

3 Al-Ișlāḥī, Fihrist 19-57.

4 Saleh, Defense 12-3.

5 Reynolds, Interpreting. 
self-representations and construction of individual identities. These features are the portrayal of childhood failures and emotions through a description of action, the narration of dreams as reflections of authorial anxiety, and the use of poetry as a discourse of emotion. ${ }^{6}$ In doing so, the study demonstrates that while the texts may appear less personal than modern autobiographies, they, nevertheless, still are exercises in individuation and clearly communicate their authors' personalities. Where they differ, however, is in what they represent. Within the Arabic tradition "[ $t]$ he autobiography did not represent a unique moment for self-representation but rather a frame or summation for revealing a certain portrait of the whole, a context within which one's work would then be placed and evaluated."7 The primary purpose, then, of many of these autobiographies was to demonstrate their authors' positions within and relationship with the broader transmission of knowledge through, for example, reference to their lineages, the authority they acquired through their education, and their contributions to that knowledge.

An interesting observation is the existence of direct historical connections between many of the texts and their authors. That is, when taken as a whole, the autobiographies reveal a recurring pattern of historical "clusters" of autobiographical production by authors who were either personally acquainted or who had read each other's texts. Moreover, in some cases, the autobiography of a particularly influential or respected scholar seems to have motivated the writing of an entire sequence of autobiographies.

One such cluster appears in the mid-9th/15th century and continues into the 10th/16th century. This cluster, which is particularly large, revolves around Ibn Ḥajar al-'Asqalānī (d. 852/1449), who penned a number of autobiographies and who was emulated by a number of his students. For example, alSakhāwī (d. 902/1497) included a substantial autobiography in al-Daw' al-lāmic $f \grave{c}$ a'yān al-karn al-tāsic and penned an independent autobiography as well, and was followed by his own students, Ibn Dayba' (d. 944/1537) and Zarrūq (d. 933/1493). Another of Ibn Hiajar's students, al-Suyūṭi (d. 909/1505), wrote a substantial autobiography that was emulated by the likes of Ibn Tuulūn alDimashqī (d. 953/1546) and al-Sha'rānī (d. 973/1565). The latter's autobiography is the most expansive premodern autobiography known to modern scholarship. ${ }^{8}$ There was, evidently, something in the air in the 9 th/15th century, and it is against this backdrop that al-Biqâ̄î̀s own autobiography was produced. As

6 Reynolds, Interpreting 243.

7 Ibid. 247 .

8 On his cluster of autobiographies, see Reynolds, Interpreting 56 . 
will be detailed below, he was himself a student of Ibn Ḥajar al-'Asqalānī and owed much of his success to him.

Inspired on the one hand by the observations made in Interpreting the self and on the other by the Geertzian concept of "thick description,"9 this chapter will move beyond a brief and positivist reconstruction of al-Biqāî̀s life and treat his autobiography not merely as an innocent record of his early life, through which we can reconstruct the chronology of his formative years, but also as a carefully crafted literary work in its own right. There was a reason why al-Biqā̄i $\overline{1}$, at 32 years of age, decided to write his autobiography: it is a text with a purpose, and it was designed to communicate. The contention of this article is that al-Biqāî's autobiography can be read in two ways: one simple and textual; the other complex and subtextual. On the one hand, it can be read positively as an account of his formative years; on the other hand, it can be read as an attempt to give meaning to those years. This article will, therefore, take a twofold approach to the autobiography, dealing firstly with what al-Biqāi tells us about his formative years before moving to exploring how al-Biqāì sought to give meaning to them and what he intended to communicate.

\section{2 The 'Unwān al-Zamān}

A number of manuscripts of the Unwān al-zamān survive. A 9th/15th-century copy is held in the Köprülü Library under the classmark 1119, covering some 386 folios. $^{10}$ An incomplete and undated copy is held in the Ahmadiyya Library in Tunis under the classmark Ms Tarājim 5034, covering 193 folios. ${ }^{11} \mathrm{~A}$ second, incomplete copy, dating back to the 11th/17th century, is held in the Maulana Azad Library of the Aligarh Muslim University under the classmark MS 'Arabiyya akhbār 40, covering 166 folios and mistitled as the Kitāb al-țabaqāt al-shäfíiyya. The Dār al-Kutub holds a copy under the classmark Ms Ta'rīkh 4911, which consists of four parts (the first consisting of 256 folios; the second 250; the third 264; the fourth 194) and which was copied in 1352/1933 by Muhammad Qināwī. ${ }^{12}$ The Taymūr collection, housed at the Dār al-Kutub, also contains a full copy of the 'Unwān al-zamān in four parts (consisting of 500, 426, 447, and 422 pages respectively) under the classmark M S Ta’rīkh Taymūr 2255, which was

9 See in particular Geertz, Thick.

10 Şeşen, İzgi and Akpınar, Fihris 572.

11 Manșūr, Fihris 442.

12 Dār al-Kutub al-Mișriyya, Fihris viii, 186. 
copied in 1345/1926 by Maḥmūd Șidqī. ${ }^{13}$ Both Qināwī and Șidqī worked from a photographic reproduction of ms Köprülü 1119, which is held in the Dār alKutub under the classmark MS Ta'rikh 1001 and which likewise consists of four parts. ${ }^{14}$ Reference is also made to a manuscript of the 'Unwān al-zamān being held in the Iraq Museum, but no details are available. ${ }^{15}$

The work has been partially edited by Ḥasan Ḥabashī, with the letters nūn, $h \bar{a}$, wa $w$, and $y \bar{a}$ missing. ${ }^{16}$ Habashì's edition is, however, problematic because it is not entirely clear upon which manuscripts it is based. Habashi states that he relied upon two manuscripts, the first of which was held in the Taymüriyya Library under the number 1119 and which had originated in the Süleymaniye Library; the second was a photographic reproduction held in Tunis of a manuscript located in the Ârif Hikmat Library in Medina. ${ }^{17}$ Concerning the first, it is likely that he worked from ms Köprülü 1119. The text of the edition accords well with this manuscript, and al-Iṣlāhị suggests that Habashī based his upon a photographic reproduction. ${ }^{18}$ Concerning the second, al-Iṣlāhī has argued that this cannot be Tarājim 5034 in the Ahmadiyya Library because that manuscript is not a photographic reproduction and that the manuscript held in the 'Ārif Ḥikmat Library, MS Ta'rīkh 43, is actually a copy of the Iżhār al-'așr and thus has no relationship to the 'Unwān al-zamān..$^{19}$ The issue is further exacerbated by the images following Habashi's introduction, which are a combination of images from two manuscripts of the Unwān al-zamān and the manuscript of al-Biqāî̀'s chronicle, the Ižhār al-'aṣr.

Given the uncertainty over the provenance of the edition, the present discussion relies primarily upon ms Köprülü 1119 and Ms 'Arabiyya akhbār 40. As stated above, MS Köprülü 1119 is a complete copy from the 9th/15th century, while Ms 'Arabiyya akhbār 40 is an incomplete and later copy. It was completed on Rabī‘ I 12, 1069 (December 8, 1658) by Khalīl b. 'Alī al-Husaynī al-Ṣamādī and ends midway through the biography of 'Abd al-Rahmān b. 'Anbar. Curiously, the text runs continuously, and there is no indication that Khalìl b. 'Alī al-Husaynī al-Ṣamādī was aware that his biography of 'Abd al-Raḥmān b. 'Anbar was

\footnotetext{
13 See the information available at: https://ihodp.ugent.be/bah/mmlo1\%3Aoooooo39o.

14 Dār al-Kutub al-Mișriyya, Fihris v, 273.

15 In his edition of Ibn Fahd's Mújam, Muḥammad al-Zāhī notes that Dr. Muḥammad Abū l-Afjān informed him of a copy of the Unwān in the Iraq Museum. See Ibn Fahd, Mujam 338n4.

16 Al-Biqā̄ìi, 'Unwān.

17 Ibid. i, 11.

18 Al-Iṣlāḥ̄, Fihrist 171.

19 Ibid.
} 
truncated or that the entire work was much longer. This suggests that the exemplar from which he worked was itself only partial.

The autobiography as it appears in MS Köprülü 1119 covers folios $71^{\mathrm{v}}-9^{\mathrm{r}}$ and can be divided into two distinct sections. The first of these is the more purely autobiographical, advancing as it does chronologically in the third person from al-Biqāî's birth until 841/1437, the year in which we are told the autobiography was written; this section covers folios $71^{\mathrm{v}}-3^{\mathrm{r}}$. The second section, which comprises folios $73^{\mathrm{r}}-9^{\mathrm{r}}$, begins with a cryptic dream, a reference to his studies with Ibn Hajar, and his performance of jihad and the hajj. However, the bulk of it is given over to quoting various of al-Biqā̄is's poems and provides only scant biographical information.

In M S Arabiyya akhbār 40, the autobiography spans folios $96^{\mathrm{r}}-107^{\mathrm{r}}$ and contains both of these sections, covering folios $96^{\mathrm{r}}-8^{\mathrm{v}}$ and $98^{\mathrm{v}}-106^{\mathrm{r}}$ respectively. To these, it adds a third section, comprising folios $106^{\mathrm{r}}-7^{\mathrm{r}}$, which is written in the first person and begins with a remembrance of his mother and then refers to events in 845/1441-2 before moving back in time to discuss his appointment as Sultan Jaqmaq's hadith teacher in 842/1438-9. The text in MS 'Arabiyya akhbār 40 is cleaner, with fewer distortions and mistakes than Ms Köprülü 1119. That being said, there are occasional passages that have been omitted in MS 'Arabiyya akhbār 40. For instance, the material that prefaces the poetry in MS Köprülü 1119 - the cryptic dream, studies with Ibn Hajar, his performance of jihad and the hajj-is not present in Ms 'Arabiyya akhbār 40.

Taken together, the differences between the two manuscripts suggest that at least two recensions of the Unwān al-zamān were in circulation. It seems likely that Ms Köprülü 1119 contains al-Biqāī's earliest extant attempt to compose his autobiography and represents how he conceived of his formative years in 841/1437. Contrarily, the text of MS 'Arabiyya akhbār 40, which must date back to circa $845 / 1441-2$ because it does not mention anything after this year, is the revised version of the autobiography, to which al-Biqāî added additional material. ${ }^{20}$ The following discussion will focus primarily on how al-Biqā'i presented his formative years in Ms Köprülü 1119 and will then discuss how the additional material in Ms 'Arabiyya akhbār 40 corroborates or modifies these conclusions.

20 It is unclear whether the material present in ms Köprülü 1119 and absent in Ms 'Arabiyya akhbār 40 was omitted by al-Biqā̄ī as part of his revision or by Khalìl b. 'Alī al-Ḥusaynī al-Ṣamādī in the process of copying the work. 


\section{3}

\section{A Positivist Approach}

Al-Biqāà begins his autobiography with an extended discussion of his lineage before moving to his birth in the village of Khirbat Rūhāa in al-Biqāa al-'Azīzì and thence to the murder of his father, two of his uncles, and six other relatives in Shabān 821/September 1418. As a result of this, his mother and maternal grandfather took him to Damascus in 823/1420, where he embarked in earnest upon his rihla fi talab al-ilm, which concerns the bulk of the autobiographical material. He provides the names of a select few of the shaykhs with whom he studied and copious titles of the books with which he became acquainted. He concludes this first section of the autobiography with a number of dreams and visions.

Al-Biqāî thus provides a wealth of information with which we can reconstruct his formative years. The autobiography is furthermore so replete with dates - when he met certain shaykhs and when he visited particular citiesthat we can pinpoint his movements in particular periods. We know, for instance, that he first traveled to Cairo in 834/1430-1 and began studying with Ibn Ḥajar al-'Asqalānī, that he traveled to Jerusalem at the end of 834/1431 to study, among other works, the Sunan of Abū Dāwūd, before returning to Cairo in early 835/1431. This chronological information has been schematized in Table 10.1. Instead, our focus will be on the information al-Biqā'i provides about his lineage and his origins and those shaykhs he singles out in his autobiography.

\subsection{Lineage and Origins}

After recounting his lineage, Ibrāhīm b. 'Umar b. Ḥasan al-Rubāṭ b. 'Alī b. Abī Bakr al-Biqāī al-Shāfīi Abū l-Ḥasan al-Ribāt, al-Biqāīi tells us that he was from a village called Khirbat Rūhā in al-Biqā' al-'Azīzī and that he was from the Banū Ḥasan, of which there were three branches: the Banū Yūnus, the Banū 'Alī, and the Banū Makkī. These branches settled throughout al-Shām, with groups in the country of Aleppo, Majdal Ma'ush-one of the villages in the north of the Biqā - and in the lands of Karak al-Shawbak. He further states that this village of some 500 inhabitants_-presumably Khirbat Rūhā — was where the Banū Hasan originated. It was from this original village that a final group emigrated to the region of Bilbays in Egypt. ${ }^{21}$

\footnotetext{
21 MS Köprülü 1119 fol. $71^{\text {v }}$; MS 'Arabiyya akhbār 40 fol. $96^{\text {r }}$; al-Biqā̄īi, 'Unwān ii, 61.
} 
TABLE 10.1 Chronology of al-Biqa'ī's formative years

Year Event

\begin{tabular}{|c|c|c|}
\hline $8 \circ 9$ & & Birth of al-Biqāề in the village of Khirbat Rūḥā in al-Biqā' al-'Azīzì. \\
\hline 821 & Sha'bān 9 & Al-Biqāî̀’s family, the Banū Ḥasan are attacked. \\
\hline & & $\begin{array}{l}\text { Death of his father and two uncles; the young al-Biqāici is left seriously } \\
\text { injured. }\end{array}$ \\
\hline 823 & & $\begin{array}{l}\text { Al-Biqāīi and his surviving family members arrive in Damascus, where } \\
\text { al-Biqāî̀ begins studying the qirāâat. }\end{array}$ \\
\hline 826 & & $\begin{array}{l}\text { Al-Biqāēi begins studying grammar, șarf, and fiqh with Abū Ḥāmid Tāj } \\
\text { al-Dīn Muḥammad b. Bahādur Sibt b. al-Shahīd. }\end{array}$ \\
\hline 827 & & $\begin{array}{l}\text { Arrival of Ibn al-Jazarī in Damascus, with whom al-Biqā'ì studied the } \\
\text { 'ashr and memorized his didactic poem, Tayyibat al-nashr fi al-qirāāat al- } \\
\text { 'ashr. }\end{array}$ \\
\hline & & $\begin{array}{l}\text { Al-Biqāīi travels to Jerusalem and studies hisāōb with al-'Imād Ismā̄ill b. } \\
\text { Sharif, a student of Ibn al-Hāim. }\end{array}$ \\
\hline & Ramaḍān & Death of al-Biqāììs mother. \\
\hline & Dhū al-Qa'da & Return of al-Biqāeì to Damascus. \\
\hline & & Al-Biqāīi studies the treatise of al-Ḥāwā with Ibn Qāḍī Shuhba. \\
\hline 831 & Ramaḍān & Death of Ibn Bahādur. \\
\hline 832 & Beginning & $\begin{array}{l}\text { Al-Biqāīi travels to Jerusalem, and studies with Zayn al-Dīn, one of Ibn } \\
\text { al-Hāìm's students, and again with al-'Imād Ismācill b. Sharif. }\end{array}$ \\
\hline 834 & & Arrival of al-Biqāīi in Cairo. \\
\hline & & $\begin{array}{l}\text { Beginning of his association with Ibn Hajar al-'Asqalānī, with whom he } \\
\text { studies hadith. }\end{array}$ \\
\hline
\end{tabular}

\begin{tabular}{|c|c|c|}
\hline & End & $\begin{array}{l}\text { Al-Biqāî̀ travels to Jerusalem and studies the Sunan } A b \bar{\imath} D \bar{a} w \bar{u} d \text { and other } \\
\text { works. }\end{array}$ \\
\hline 835 & Beginning & Al-Biqāīì returns to Cairo. \\
\hline 836 & & $\begin{array}{l}\text { Al-Biqāīi accompanies Ibn Hajar on al-Ashraf Barsbay's campaign against } \\
\text { Qarā Yulūk; he studies with a number of shaykhs, the most prominent of } \\
\text { whom was Shaykh Burhān al-Dīn al-Muhaddith, Hāfiẓ al-Shām. }\end{array}$ \\
\hline \multirow[t]{3}{*}{837} & & $\begin{array}{l}\text { While returning to Cairo, al-Biqāî̀ stops in Damascus and recites to the } \\
\text { shaykhs there. }\end{array}$ \\
\hline & & Al-Biqāci travels to Damietta and Alexandria. \\
\hline & & Al-Biqā̄ì returns to Cairo. \\
\hline 841 & & $\begin{array}{l}\text { Al-Biqāî̀ writes the first part of his short autobiography in the 'Unían } \\
\text { al-zamān. }\end{array}$ \\
\hline 842 & & $\begin{array}{l}\text { On the recommendation of Ibn Hajar, al-Biqāè is appointed to teach } \\
\text { hadìth to Sultan Jaqmaq in the Citadel of Cairo. }\end{array}$ \\
\hline & & Beginning of his position as the mufassir at the Zāhir Mosque in Cairo. \\
\hline
\end{tabular}


Al-Biqāî̀ then moves to position himself within the Banū Ḥasan. Although he is forthright about the fact that he does not know his lineage beyond his great-great-grandfather, Abū Bakr, through comparison with the lineages of two of his relatives, whom he refers to as his ibn ' $\mathrm{amm}$, he concludes that he is likely from the Banū Makkī. His relatives were called Muhammad b. Hasan b. Makkī b. 'Uthmān b. 'Alī b. Ḥasan and 'Alī b. Muhammad b. Yūsuf b. 'Alī b. Yūnus b. Ḥasan. Al-Biqāî̀ argues that his relatives count only four generations between themselves and Hasan and that because they claim descent from 'Alī b. Ḥasan and Yūnus b. Ḥasan, respectively, then he must be descended from Makkī b. Hasan. Al-Biqā̄ī further notes that while he does not know his lineage beyond Hasan, he has been told that the Banū Hasan "traced their lineage to Sa'd b. Abī Waqqāṣ al-Zuhrī, one of those who will witness Paradise," and that the uncle of Muhammad b. Hasan believed that they had a nisba that confirmed this. ${ }^{22} \mathrm{Al}$-Biqāî's attempts to discover this nis $b a$, however, were confounded. While traveling with Ibn Ḥajar toward Āmid as part of al-Ashraf Barsbay's 836/1433 campaign against Qarā Yulūk, he asked a group of his relatives in Damascus about the nisba; although they deemed it credible, the nisba itself was unknown. ${ }^{23}$

The main point to be made about al-Biqāî's knowledge of his genealogy is the "fuzziness" of the link between his extended kin group and their ostensible ancestor, Sa'd b. Abī Waqqās. In many ways, his knowledge of his genealogy recalls how modern Bedouin remember and record their genealogies. Like modern Bedouin, al-Biqā̄i is more knowledgeable about the microgenealogy of his immediate kin group but is otherwise vague about his genealogy. That he "must have been" a descendant of Makki b. Hasan likewise recalls how Bedouin arrange their genealogies according to what is believed rather than what is known. Like modern tribesmen, al-Biqāī and his extended kin group remembered what was useful for them - everyday relationships-and forgot that which had no practical import - their links to an ancient ancestor. ${ }^{24}$

In this way, al-Biqāîi's genealogical knowledge allows us not only to reconstruct how he conceived his extended kin group but also suggests that he was among the first of his family to make the transition into a more urbanized and literate society. As Zoltán Szombathy notes: "increasing urbanization and literacy seem regularly to result in an ever greater, rather than lessened, care

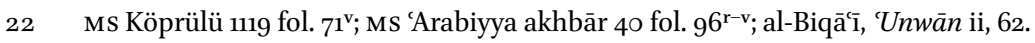

23 Ms Köprülü 1119 fol. $71^{\text {v}}$; MS 'Arabiyya akhbār 40 fol. $96^{\mathrm{v}}$; al-Biqā̄ì̄, 'Unwān ii, 62.

24 The utility — and problems — of using the genealogical knowledge of modern Bedouin to understand premodern genealogical knowledge has been outlined by Hugh Kennedy. See Kennedy, Oral. On Bedouin genealogy more generally, see Lancaster, Rwala.
} 
over genealogies: the more literate and scholarly a community is, the greater degree of precision is needed in formulating nasab relationships before they can gain widespread recognition ... the keeping of nasabs (hifz al-nasab) is incomparably more meticulous in urban communities than among nomads."25 That al-Biqāī does not have more meticulous knowledge of his nasab suggests that he was the first of his family to be exposed to the mores of the scholarly urban communities. This transition is perhaps more fruitfully understood, not necessarily as one from an oral tradition to a literate tradition, as Szombathy and Kennedy suggest, but as a transition from the periphery to the center, both physically and intellectually.

Indeed, the autobiography is fundamentally an account of how he made this intellectual transition. This is, of course, hardly surprising considering that it is contained within a biographical dictionary of his teachers and peers. The autobiography and the Unwān al-zamān have the same function: they are designed to underscore his transition from his peasant background to membership in the intellectual elite by memorializing those links he had established with the intellectual elite. Where the Unwān al-zamān is the autobiography writ large, the autobiography is the Unwān al-zäman writ small. In this sense, we can understand the scholars al-Biqā̄i mentions in his autobiography as particularly influential. That is, these are the links he sought to emphasize over all others. It behooves us, then, to examine further which scholars he chose to mention.

\subsection{Shaykhs}

The shaykhs al-Biqāìi names in his autobiography can be divided into two categories: those who most influenced the direction of his education and those who were particularly famous in 15 th-century intellectual circles. In the case of the latter, his giving pride of place to prominent scholars is one way in which he could gain for himself some measure of the social capital that accrued to their names. These categories, as will be seen, are not mutually exclusive. In terms of balance, however, it is clear that al-Biqāî affords more attention to his influential teachers than he does to his famous teachers. ${ }^{26}$

\footnotetext{
25 Szombathy, Genealogy 27.

26 There is an issue here of circularity when it comes to determining which of the scholars he mentions were prominent; scholars deemed prominent today are not necessarily those who were considered prominent by their peers. Oftentimes, it can come down simply to the vagaries of chance, which allowed the works of one scholar to survive over those of another. This is compounded by the fact that the biographical sources from which we work have interpretative schema—often unarticulated — which in turn delineate "fame" and "importance" in particular ways.
} 
Thus, al-Biqāì tells us that after his arrival in Damascus in 823/1420, he began studying the Quran and came to know the seven versions of the qiräàt. He also memorized part of the Hirz al-amānī fì wajh al-tahānì of al-Shāțibī (d. 590/1194). ${ }^{27}$ His teacher during this time was Sharif al-Dīn Ṣadaqa b. Salāma b. Ḥusayn al-Ḍarīr al-Masharāōī (d. 825/1422). ${ }^{28}$ Sharif al-Dīn al-Masharā'ī enjoyed a reputation as a preeminent scholar of the qiräāt, and with him, al-Biqāī also began to study the tajwìd of the Quran. Very little is recorded about Sharif al-Dīn al-Masharâ̄'̄ , with his most extensive biographies being provided by al-Biqā̄ī and, not unexpectedly, al-Sakhāwī. ${ }^{29}$ Otherwise, Sharif alDīn al-Masḥarāī appears in Ibn al-Jazarī’s Ghāyat al-nihāya fìțabaqāat al-qurrā', a biographical dictionary of Quranic reciters. ${ }^{30}$ The information provided by all of these biographies is scant and primarily focused upon Sharif al-Dīn alMasharā'î's own studies and work on the qirāàat.

The year after the death of Sharif al-Dīn al-Masḥarāì̄, al-Biqāài began studying grammar and figh with Tāj al-Dīn Abū Ḥāmid Muḥammad b. Bahādur b. 'Abdallāh al-Jalālì (d. 831/1428). ${ }^{31}$ Much like Sharif al-Dīn al-Masḥarāīì, Ibn Bahādur made little impact in the biographical literature of the period. AlBiqāīi and al-Sakhāwī are his only biographers of note. Ibn Bahādur was born at the end of the 8th/14th century and was the grandson of one Fath al-Din b. al-Shahīd, about whom no information seems to have survived. He devoted himself to the study of the Quran and became distinguished for studying it. AlBiqāīi continued to study with Ibn Bahādur until the latter died in Ramaḍān 831/June 1428. Touchingly, al-Biqāīi tells us of his teacher that he, al-Biqā̄ì, "did not profit from anyone as he profited from him." ${ }^{32}$

Concurrently, al-Biqāì appears to have developed a sustained and fruitful relationship with one al-'Imād Ismāîl b. Ibrāhīm b. Sharif, with whom he began

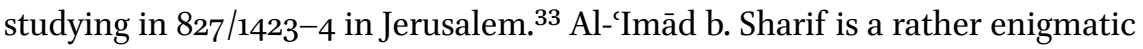

27 This work is known best as al-Shātibiyya. It was a versification of al-Dānī's compendium of the qirāàt, entitled the Kitāb al-taysìr.

28 Ms Köprülü 1119 fol. $72^{\text {r }}$; MS 'Arabiyya akhbār 40 fols $96^{\mathrm{v}}-7^{\mathrm{r}}$; al-Biqāī, 'Unwān ii, 62.

29 For al-Biqāî̀'s biography of Sharif al-Dīn al-Masharā̄ì, see Ms Köprülü 1119 fol. $112^{\mathrm{r}}$. Curiously, Sharif al-Dīn al-Masḥarā̄ì is missing from ms 'Arabiyya akhbār 40. See also alBiqā̄ì̄, 'Unwān iii, 47-8. For al-Sakhāwī's biography, see al-Sakhāwī, al-P̣aw' iii, 317-8. AlSakhāwī's obsession with al-Biqāîi is well known, and it was so extensive that he provides substantial biographical information about those who crossed paths with al-Biqā̄ì. On this, see Saleh, Defense 8-10.

$30 \quad$ Ibn al-Jazarī, Ghāyat i, 304, no. 1461.

31 For al-Biqā̄ī’s biography of him, see ms Köprülü 1119 fols $233^{\mathrm{v}}-4^{\mathrm{r}}$; al-Biqā̄̄ì, 'Unwān v, 112-4.

32 Ms Köprülü 1119 fol. $72^{\text {r }}$; MS 'Arabiyya akhbār 40 fol. 97' ${ }^{\text {r }}$ al-Biqāî̀, 'Unwān ii, 63 .

33 Ms Köprülü 1119 fol. $72^{\text {r }}$; Ms 'Arabiyya akhbār 40 fol. 97'; al-Biqā̄ì, 'Unwān ii, 63 . 
figure. ${ }^{34} \mathrm{Al}-\mathrm{Biq} a \bar{a} \mathrm{i}$ himself knew little about him beyond an approximate birthdate of $782-3 / 1380-2$. The lack of a death date suggests that he was still alive when al-Biqāīi wrote the Unwān al-zamān. Al-Imād b. Sharif was a student of Ibn al-Hāiim (d. 815/1412),,35 himself an expert in farāì and hisāb, and was responsible for directing al-Biqāî’s studies concerning hisāa b. These studies involved memorizing two manzüma of Ibn al-Hāiim: one on algebra and the other on the formulas of the Bedouin. Later in $8_{32}$, al-Biqāi returned to Jerusalem and studied Ibn al-Hāiim's al-Wasīla with another of Ibn al-Hāiim's students, Zayn al-Dīn. He also studied mathematics, fușūl, and the division of estates with him. During this visit, al-Biqāī resumed his studies with al'Imād b. Sharif, focusing on the Sharh nukhba al-muhaddithin of Ibn Ḥajar al-'Asqalānī. ${ }^{36}$

During this period, al-Biqāīi encountered two prominent scholars: Ibn alJazarī (d. 833/1429) and Ibn Qāạī Shuhba (d. 851/1448). ${ }^{37}$ Al-Biqā̄ì was particularly impressed by Ibn al-Jazarī, who visited Damascus in 827/1423-4 and whom he lauds as the "most learned of the time, the Shātibī of the age." ${ }^{38}$ With Ibn alJazarī, al-Biqā̄ì read aloud from the 'ashr and also memorized Ibn al-Jazarī's didactic poem, the Tayyibat al-nashr fi al-qirā'āt al-'ashr. Al-Biqā̄ì showed Ibn al-Jazarī his first muṣannaf and was authorized by Ibn al-Jazarī to read what they had studied together. Later, in $831 / 1427-8$, he studied al-Hâw - - a textbook of Shāfi'i figh composed by Najm al-Dīn al-Qazwīn̄ (d. 655/1266)—with Ibn Qādī Shuhba. This seems to be a continuation of his earlier studies of a versification of $a l-H \bar{a} w \bar{\imath}$ by Ibn al-Wardī (d. 749/1349). Neither of these relationships seems to have endured, at least insofar as his autobiography suggests.

This was followed in 834/1430-1 by the beginning of al-Biqāî̀'s association with Ibn Hajar, with whom he studied extensively. Among the works he studied with Ibn Hajar were the Sharh nukhbat al-muhaddithīn (from which al-Biqā̄ī tells us he benefited greatly), al-Ta'iikh al-mufannan, and the majority of Sharh alfiyyat al-irāqū fì 'ulüm al-hadìth. Ibn Hajar authorized al-Biqāì to teach and defended al-Biqāî̀ during the judicial contest concerning his future recitation of al-Bukhārī (likely a reference to al-Biqāề's appointment as Sultan Jaqmaq's hadìth teacher) by commending a composition by al-Biqāìi, al-Allàma. ${ }^{39}$ The

\footnotetext{
34 For al-Biqāīìs biography of him, see Ms Köprülü 1119 fol. $92^{\mathrm{v}}$; MS 'Arabiyya akhbār 40 fol. $123^{\mathrm{r}}$; al-Biqā̄ì', 'Unwān ii, 135 . Ibn Qāḍī Shuhba, Tabaqāt iv, 17-8.

36 Ms Köprülü 1119 fol. $72^{\text {r }}$; MS 'Arabiyya akhbār 40 fol. $97^{\text {r }}$; al-Biqā̄i, 'Unwān ii, 63 .

37 Ms Köprülü 1119 fol. $72^{\text {r }}$; MS 'Arabiyya akhbār 40 fol. $97^{\mathrm{r}}$; al-Biqā̄ì, 'Unwān ii, 63 .

38 Ms Köprülü 1119 fol. $72^{\mathrm{r}}$; Ms 'Arabiyya akhbār 40 fol. $97^{\mathrm{r}}$; al-Biqā̄ī' 'Unwān ii, 63 .

39 Ms Köprülü 1119 fol. $72^{\text {r }}$; MS 'Arabiyya akhbār 40 fol. $97^{\text {r }}$; al-Biqā̄i, 'Unwān ii, 64 .
} 
closeness of their relationship is suggested by their traveling together to Āmid as part of al-Ashraf Barsbay's 836/1433 campaign, and its simple longevity.

Other names are mentioned in the autobiography. He makes references to studying with the shaykhs of Aleppo and Damascus, though the onomastic information he provides is too scant to permit the identification of them all. Additionally, al-Biqāi tells us of the traditionists with whose students he studied. This is essentially a list of primarily 14 th-century scholars: Abū l-Fath Muḥammad b. Muḥammad al-Maydūmī (d. 655/1257), 'Alā l-Dīn Mughlāțāy (d. 762/1361), al-Ṣalāḥ b. Abī 'Amr b. Amayla, al-Subkī (d. 756/1355), Ibn Nubāta (d. 768/1366), and Șalāḥ al-Dīn Khalīl b. Kaykaldī l-'Alāī (d. 761/1359).

It is clear that al-Biqāi was more interested in recounting his interactions with those teachers who fundamentally shaped his intellectual life than he was in co-opting the social capital of prominent 15 th-century scholars. Of the three scholars who are regarded by modern scholarship as particularly famous, only Ibn Hajar is afforded anything approaching prominence. Al-Biqāī's biography of Ibn Hajar is expansive ${ }^{40}$ his biography of Ibn al-Jazarī barely five lines, ${ }^{41}$ and his biography of Ibn Qāḍi Shuhba nonexistent.

When we read the autobiography positively, we can begin to reconstruct alBiqāî's social and especially his intellectual contexts, outline the curriculum he followed, and see in which particular intellectual traditions he operated. Yet this is only one approach of the autobiography: it also functions more explicitly as an attempt by al-Biqāi ì to give meaning to his formative years. To explore this further, we will focus our attention on three elements of the autobiography. Firstly, we will return to his account of his lineage. Secondly, we will turn to his use of dreams. Thirdly, we will explore how he treats the attack on his family in Sha'bān 821/September 1418.

\section{$4 \quad$ Semiotizing the Self}

\subsection{Lineage Revisited}

It was, of course, not unusual for scholars to recount their lineages. Within the

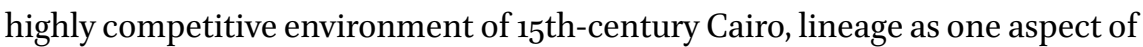
hasab wa-nasab was of central importance. ${ }^{42}$ It was a marker of social status and prestige, one of the ways in which membership of the intellectual elite was both recognized and reproduced. What is curious, though, is why al-Biqāi $\overline{1}$

\footnotetext{
40 Ms Köprülü 1119 fol. $18^{\mathrm{r}}-34^{\mathrm{v}}$; MS 'Arabiyya akhbār 40 fol. $26^{\mathrm{v}}-49^{\mathrm{r}}$; al-Biqāầ, 'Unwān i, 115-80.

41 MS Köprülü 1119 fol. $348^{\text {r }}$.

42 On this, see Ed., Ḥasab.
} 
chose to include the information he does. While it allows us to reconstruct how he understood his genealogy and the geographical range of his extended kin group, the process of writing it down made the lacunae in his genealogical record - unimportant in his original social context—highly visible. That is, by recording his genealogy, al-Biqā̄i highlights the "fuzziness" of his knowledge of the link between himself and Sacd b. Abī Waqqās. Al-Biqāì draws attention to the fact that his lineage was categorically not illustrious. It could not, therefore, serve to highlight his social status. The question, then, is why he included it at all.

That he goes to such lengths to provide any and all information that he can about his lineage suggests that he was aware of how limited his knowledge was, but also of how valuable lineage could be. At the very least, the inclusion of this material is his way of demonstrating that while he may have come from a peasant background, he was not ignorant. He would also have been aware that given his relative lack of social standing, any attempt to claim or generate a prestigious nasab would likely have been rejected and ridiculed. As Szombathy notes, genealogy was a marker of prestige, not a generator of it, and attempts to use it to generate prestige on the part of lowly groups did not end well. ${ }^{43}$

It is in this light that we should read the suggestion that Sa'd b. Abī Waqqās was the ultimate progenitor of al-Biqāis's kin group. The attraction of Sa'd b. Abī Waqqās is obvious: he was one of the first Muslims and, as al-Biqā̄i himself tells us, one of those to whom Paradise has been promised. ${ }^{44}$ Furthermore, the Prophet was reported to have acknowledged him as his maternal uncle. "Jābir b. 'Abdallāh said, 'Sa'd approached,' so the Prophet (ș) said, 'This is my uncle, so let a man show me his uncle." 45 Sa'd b. Abī Waqqās and the Prophet's mother, Āmina bt. Wahb were both members of the Banū Zuhra, a clan of the Quraysh. Who better to be descended from than one of the first converts, a relative of the Prophet, and member of the Quraysh?

That al-Biqā̄î̀s kin group was descended from Sa'd b. Abī Waqqās is likely a family myth or legend, one which al-Biqāī was happy to recount but was reluctant to unilaterally accept and propagate, likely for the reason just mentioned. This is a tentative attempt at "genealogical parasitism," a term coined by Dennis D. Cordell in his study of Dar al-Kuti and applied by Szombathy to medieval Muslim societies, which refers to the practice of grafting new lineages and fam-

43 Szombathy, Genealogy 12, 16-8.

44 Al-Tirmidhī, al-Jāmic vi, 100, no. 3747; Ibn Mājah, Sunan 144, no. 133; Abū Dāwūd, Sunan vii, 46 , no. 4649 .

45 Al-Tirmidhī, al-Jāmic vi, 104, no. $375^{2}$. 
ilies onto the standardized medieval genealogical stem. ${ }^{46}$ While categorically claiming descent from Sa'd b. Abī Waqqās would have opened him up to the risk of censure, al-Biqāi mentions the family myth in order to preserve the possibility of his kin group's descent from Sa'd b. Abī Waqqās. He did so on the chance that he and his descendants would prove illustrious enough for their genealogy to become accepted. The prestigious have always found the preservation of spurious lineages easier than the lowly.

An apposite example of this is provided by Jo Van Steenbergen in his discussion of Ibn al-Qaysanārīs (d. 1352) panegyric for al-Mālik al-Șāliḥ Ismāîl. The panegyric was Ibn al-Qaysanārīs attempt to demonstrate his historiographical and belletristic skills, as part of which he emphasized his own administrator's pedigree as a member of a longstanding Syrian family that claimed descent from Khālid b. al-Walīd (d. 21/642), the Sword of Islam. ${ }^{47}$ This was despite the fact that by the 14th century, Khālid b. al-Walīd's line was considered long extinct by the scholars of nasab. ${ }^{48}$ Evidently, this was no concern for Ibn al-Qaysanārī because he had the symbolic capital of his prestigious forebears behind him. Al-Biqāīi had no such resource, and so he could not risk making any definitive claims vis-à-vis Sa'd b. Abī Waqqās but nevertheless hoped that he and his descendants would generate such capital. That this did not happen is amply demonstrated by the silence of his later biographers concerning his ostensible descent from Sa'd b. Abī Waqqās.

Al-Biqāî̀'s extended discussion of his lineage, despite his inability to provide much detail, was thus intended to provide the foundation for his entry into the

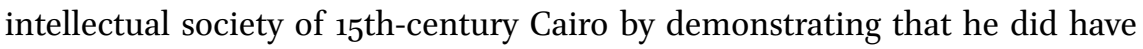
knowledge of his lineage, while simultaneously attempting, circumspectly, to arrogate for himself and his kin group the prestige of Sacd b. Abī Waqqās. That he sought to do so suggests a degree of authorial anxiety on the part of al-Biqāi $\overline{1}$, which is underscored by his use of dreams.

\subsection{Dreams}

Reynolds notes that the narration of dreams in biographical and autobiographical literature is primarily tied "in one way or another, to issues of authorial anxiety: the author argues in dream narrations (dreamed by himself or others) points that he feels he cannot argue on his own authority."49 Now, al-Biqā'i

\footnotetext{
$46 \quad$ Szombathy, Genealogy 5 .

47 Van Steenbergen, Qalāwūnid.

48 Ibn Fạ̣l Allāh al-'Umarī, Masālik iv, 177.

49 Reynolds, Symbolic $261-86,276$. This chapter is a much expanded version of Reynolds's discussion of dreams found in Interpreting 88-93.
} 
can hardly compete with the sheer volume of dreams some scholars included in their autobiographies, ${ }^{50}$ but his dreams nevertheless perform a similar semiotic function. Only two dreams are narrated in any great detail; the first explains the origins of his grandfather's peculiar laqab "al-Rubāt,"51 while the second is recounted by his maternal cousin concerning a head injury al-Biqāī received when he was younger. It is to the second dream that we will turn our attention.

Al-Biqāī introduces it by explaining that God blessed him in numerous ways, the greatest of which was perhaps that this head injury was cured by the Prophet. The account proceeds thus:

God Almighty rewarded him [al-Biqāīi] from His Grace with many and obvious kindnesses of His miracles, amongst the greatest of which-or the greatest-was that he was injured in the head when he was small, and the Prophet (s) cured him, which is to say that the daughter of his maternal uncle, Maryam bt. Muhammad b. 'Alī b. Muhammad b. Sulaymān, saw him (ṣ) in a dream, wherein he said to her: "You have one wish from me." She said to him: "The son of my paternal aunt is injured in his head." So he said to her: "Take this remedy to him, and shortly afterwards it will be healed, as if his head had never been injured." His maternal cousin remained after the dream unable to raise the hand to which he had given the remedy. ${ }^{52}$

Within Islamic oneirocriticism, dreams of the Prophet Muhammad were deemed to be both unequivocally true and divinely inspired: they couldand did, as Leah Kinberg has demonstrated-function in a similar manner to hadith. ${ }^{3}$ True dreams correlate closely with issues of authority—particularly of a spiritual nature-and social rank.

Al-Biqāei's inclusion of a "true" dream, the meaning of which is obvious, was designed to substantiate his status. Given the broader framework of the autobiography, this was likely his intellectual status. It is significant that his recovery from what was, evidently, a serious injury is presented as miraculous and facilitated solely through the intervention of the Prophet. The truth of the dream, in no need of confirmation due to it being of the Prophet, is nevertheless corroborated by the subsequent physical impairment of his cousin.

$5^{\circ} \quad$ For example, Abū 'Abdallāh al-Tirmidhī and Abū Shāma included 17 and 14, respectively.

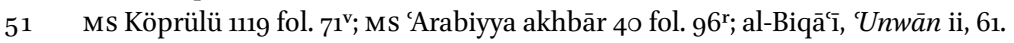

$5^{2}$ Ms Köprülü 1119 fol. $72^{\text {v }}$; MS 'Arabiyya akhbār 40 fol. $98^{\text {r }}$; al-Biqā̄ì̄, 'Unwān ii, 65 .

53 Kinberg, Literal. 
Al-Biqāî does refer to other dreams, though he merely tells us that he saw the Prophet in many dreams (in some of which he kissed his hand) and that he also saw Abū Bakr, 'Umar b. al-Khațtāb, and 'Alī b. Abī Ṭālib. Al-Biqāì tells us that he "kissed the left hand of 'Alī." "W4 Why al-Biqāì chooses not to describe the events of these dreams is unclear, though they still have a legitimizing function, which is enacted by listing the names of those who appeared and by positioning these names after his narration of the dream of his cousin, Maryam bt. Muhammad. Much like the reference to Sa'd b. Abī Waqqās was an attempt to arrogate for himself some measure of Sa'd's prestige, so too are these dreams attempts on the part of al-Biqāi to enhance his prestige through association with the Prophet and three of the rightly guided caliphs. In this way, they are meant to assuage the problem of his lack of social standing.

\subsection{The Attack on His Family}

It is clear that the attack on his family, which resulted in the death of his father, is the crux of the autobiography, though he does only describe it briefly. $\mathrm{He}$ states that "the șăhib al-tarjama was born in approximately 8og in Khirbat Rūhāa ... There, he read the Quran and laboured in it. Then an event committed outrage against them, in which his father, his two uncles, and six of his relatives were treacherously killed in Sha'bān 821. Thereupon his mother and her father took him to Damascus in 823." ${ }^{.55}$ Although he does not explicitly link the death of his father with the serious injury he received as a child, we can infer from his treatment of the events that they were both consequences of the attack on his family because they are semiotized in the same way.

Concerning the death of his father, al-Biqāì tells us that he heard an unseen voice when he was younger. The notion of the unseen voice, the hätif, is closely related to dream symbolism and functions in a similar way. He states that

when he was a boy in Khirbat Rūhā he attended a mosque called the zāwiya of Shaykh Mūsā, wherein he studied by himself. He heard therein a speaker, and he could not see anyone; there was no place for anyone to conceal himself. He [the speaker] said to him: "They will kill your father!" verbatim and repeatedly. And therefore he used to hear this

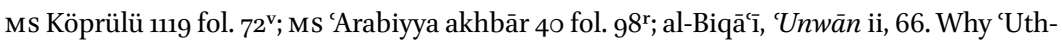
mān was the only one of the Rāshidūn not to appear in al-Biqāî's dreams is unclear, as is the significance of 'Ali's left hand. 
phrase whenever he would pass the graveyard of the companions of the $z \bar{a} w i y a$; then his father was killed shortly thereafter. ${ }^{56}$

This is clearly a portent of future events and is intended to give meaning to the death of his father. The warning transfers it from the realm of the mundane and the random into the realm of prophecy. It is no longer an act of meaningless violence but an event pregnant with meaning. Likewise, when he introduces his maternal cousin's dream of the Prophet, this is framed within the context of the Prophet's intervention being one of the "many and obvious kindnesses" that God had bestowed upon al-Biqāīi his injury, much like the death of his father, was purposeful.

The meaning behind both events is revealed in a statement attributed to one of his anonymous companions:

One of his companions expressed the opinion to him that the Prophet (ș) had, in his opinion, sent to the șăhib al-tarjama a gift. It was one of the greatest of the graces which he had witnessed concerning trials, amongst the greatest of those was the killing of his father and his uncles, for it was a reason for his moving to Damascus. And it was the starting point of his attaining the happiness of searching for knowledge and learning about the lands of men, and witnessing miracles. ${ }^{57}$

The meaning, then, is simple: the attack on his family was neither meaningless nor purposeless. Rather, it was the greatest gift that had been bestowed upon him, for it was the driving force behind his move from the village of Khirbat Rūhā to Damascus and thence to Cairo.

Our discussion thus far has been based on Ms Köprülü 1119. How, then, does the additional material in Ms 'Arabiyya akhbār 40, which was added some four years after his appointments as Sultan Jaqmaq's hadith teacher and as the mufassir of the Zāhir Mosque, modify this picture? Covering folios $106^{\mathrm{r}}-7^{\mathrm{r}}$, this additional material makes a notable departure by switching to the first person. The effect of this is to make the additional material read in a more introspective and personal manner. Al-Biqāì begins with a remembrance of his mother. He states that she "was a good woman, but there was a severity in her character, a quality inherent in most—or all—of our relatives. When she was angry with me, she used to pray that I would die as a highwayman on the streets."58

$5^{6} \quad$ Ms Köprülü 1119 fol. $73^{\text {r; }}$ ms 'Arabiyya akhbār 40 fol. $98^{\mathrm{v}}$; al-Biqā̄ì, 'Unwān ii, 65 .

57 Ms Köprülü 1119 fol. $72^{\mathrm{v}}$; Ms 'Arabiyya akhbār 40 fol. $98^{\mathrm{r}-\mathrm{v}}$; al-Biqāāì, 'Unwān ii, 66.

$5^{8}$ Ms 'Arabiyya akhbār 4o fol. 106 . 
He continues by discussing his love for jihad, which expands upon his earlier reference to his activities as a mujāhid. Thus, he tells us that he struggled with his bodily appetites and sought to gain mastery over them; he would pray to God that He would help him in this endeavor. So great was his passion for jihad that he devoted himself to the practice of archery and swordsmanship, hoping to master both, and he began to compose a work on the science of the sword, which he hoped would become paradigmatic. ${ }^{59}$ There is thus no ambiguity that al-Biqāì devoted himself to military jihad and not to the more pacifist and ascetic mujāhida. ${ }^{60}$ While it does suggest, in particular, a somewhat more deep-seated interest in the practice of jihad than is otherwise known, this new material does little to change our semiotic reading of the autobiography so much as it adds nuance to the more positivist traditional reading.

This is, however, not the totality of the new material. The most significant part concerns his appointment as Sultan Jaqmaq's hadìth teacher. Al-Biqāī tells us that

when Sultan al-Malik al-Zāhir Abū Sa'īd Jaqmaq obtained the sultanate in the year $842 / 1438$, I enquired of the qāạt l-qudāt; and therefore did he speak on my behalf concerning the reading of al-Bukhārī in histhe Sultan's-presence because he who had been reading in that capacity was no longer competent for it. He assented and described me in my absence with reference to many attributes, amongst which was that the handsomeness of my reading was excellent. The slanderers sought to undermine that, exerting themselves and acting deceitfully.

And so, on the day on which he would select someone to read, the $q \bar{a} d \bar{\imath}$ l-qud̄at enquired of the Sultan before the reading. He said: "The one about whom you have spoken - may he be greatly reward." And he praised me concerning my knowledge and my compositions, and said: "Tomorrow, he will read and he will astonish the Sultan."61

Al-Biqāì continues by noting that "God Almighty was kind" and proved the truth of the sultan's statement by making his reading successful and that he made no "barbarism of speech" during it. He does admit that, occasionally, he would misread 'an as ibn and vice versa. He concludes the biography by noting

59 Ibid. fol. $106^{\mathrm{r}-\mathrm{v}}$.

6o More commonly referred to in Western scholarship as jihäd al-nafs, the preferred term in premodern writing is mujāhida. For discussion of this, see in particular Neale, Jihad $47-55$.

61 MS 'Arabiyya akhbār 40 fols $106^{\mathrm{v}}-7^{\mathrm{r}}$. 
the closeness of his relationship with Ibn Hajar, a point more than evidenced by Ibn Hajar's pivotal role in the advancement of al-Biqāî's career. ${ }^{62}$

Two points need to be made. Firstly, al-Biqāâìs emphasis of his gratitude that he made no mistakes during the first recitation, coupled with his candid admission that he occasionally misread ' $a n$ as $i b n$ and vice versa, suggests that much of his anxiety revolved around his speech and, by extension, his peasant background. This, in turn, suggests that al-Biqāì was consciously marked as an outsider by the Cairene intellectual elite, unnamed members of which opposed his appointment because of his less cultured background. That al-Biqāī felt the need to return to this and stress that he deserved his appointment on the basis of the excellence of his reading, and to furthermore invoke the authority of Ibn Hajar, suggests that the opposition continued to be a factor in his life.

Secondly, and strikingly, the involvement of God within the direction of his life continues. Thus, while Ibn Hajar was the one to secure his appointment, it was through neither his nor al-Biqâ̄î̀s agency that his recitation was successful. Rather, it was God who decided to be beneficent and ensure al-Biqāī’s success and thereby, al-Biqāīi continues, demonstrating to the sultan the blessings God had bestowed upon al-Biqāāi

\section{5} Toward an Ontology of History

The notion that his life was shaped by the Divine is highlighted by Guo in his discussion of al-Biqāiè's chronicle, the Iz̧hāral-'așr. Guo makes two points about the Izhār al-'așr that bear mentioning here. Firstly, he argues that the Ižhār al'aşr is fundamentally eschatological and that this can only be understood in the context of Islamic salvationist history, the central concern of which had, by al-Biqāề's time, become

more about the internal threats to the realm, about the concept of the superiority of the righteous Muslim scholars (himself included of course) and just rulers (such as Sultan Īnal) to those unjust rulers (such as Sultan Jaqmaq), corrupt officers, and phony 'ulama $\bar{a}^{\prime}$... the paramount concern for him was naturally the internal turmoil and self-destruction that was eating away at the already feeble Mamluk system ( fasād, $z u l m$ are the buzzwords in the Chronicle throughout) ${ }^{63}$

62 Ibid., fol. $107^{\mathrm{r}}$.

63 Guo, Al-Biqā̄ī’s 139. 
Secondly, Guo argues that al-Biqāầ juxtaposes and explains events from his own life with Quranic exegesis and dream symbolism. In doing so, he interprets his life symbolically within the context of this eschatological salvation history. Essentially, al-Biqā̄i sees the trials and tribulations that he undergoes as parallels to the trials and tribulations of the Muslim community at large and that just as the Muslims will be triumphant, so too will he triumph over his opponents and detractors. In both cases, Guo argues, this is because these triumphs are predictable in accordance with the "Heavenly Plan": for al-Biqā̄ì, the Divine was guiding the course of his life. ${ }^{64}$

The parallels between this sense of Divine immanence in both the Izhār al'așr and the autobiography are obvious. In the autobiography, al-Biqāî casts his life as fundamentally guided by God and defined by trial and hardship and singles out the death of his father and the opposition that he met in Cairo. In both cases, however, he is triumphant. The eschatological element is also present in the autobiography, though somewhat more muted. Al-Biqāìi notes the following:

At the end of the 23rd night of the month [Dhū l-Hijja] in the year [845/4th of May 1442], I saw whilst dreaming a reciter reading in my house: "The Hour $\left[a l-s \bar{a}^{\prime} a\right]$ drew near and the moon was cleft in two." Thus is it auspicious from its beginning with the imminence of al-Amr and its end with the attainment of benefit. And God Almighty makes near the realization of that, because He is over all things capable. ${ }^{65}$

The reciter quotes Q 54:1 verbatim, which has intrinsic eschatological meaning. The Hour, for which al-amr is frequently a synonym, ${ }^{66}$ refers to the period immediately preceding the end of the world. The splitting of the moon asunder is one of the more dramatic signs of the imminence of the end. Al-Biqāî's commentary on his dream, wherein he expresses his hope for the realization of this, suggests that he believed himself to be living in the End Times. The autobiography demonstrates that al-Biqāî's belief in the imminence of the Divine in his life and the eschatological future were not unique to the Izhār al-așr. Rather, it suggests that these were fundamental elements in al-Biqāîis ontology of history, which had developed at least some fourteen years earlier when he wrote his autobiography.

$64 \quad$ Ibid.

65 Ms 'Arabiyya akhbār 4o fol. 106v .

66 Lawson, The Quran xxi, xxiii, 33. 
Al-Biqāî̀'s autobiography can thus be read in two ways. On the one hand, it can be read positively as an account of his formative years; on the other, it can be read as an attempt to give meaning to those years. In truth, both of these aspects work together to support al-Biqââi's position within the intellec-

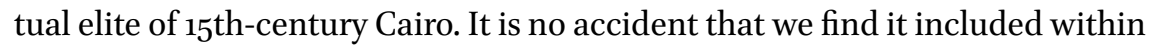
his biographical collection. The writing of biographical collections is fundamental to the formation and maintenance of group identities. The periodic updating and compilation of these works is an attempt to assert continuity between the present and the past because the present gains its authority by virtue of the weight of memory. Biographical collections were the battlegrounds on which membership in the intellectual elite was fought. Inclusion in them was a marker of success; exclusion a marker of failure.

Thus, if we read the autobiography positively as a record of his early years, his choice to focus on his rihla fi talab al-ilm communicates and underscores his membership in the intellectual elite by stressing and memorializing the links he developed between himself and the members of the intellectual elite, particularly his relationship with Ibn Ḥajar al-'Asqalānī. By including himself within his collection, he claims for himself a place within that intellectual community.

When we read the autobiography as an attempt to develop meaning, it becomes not merely an attempt to justify his membership among the intellectual elite but also the record of how al-Biqāî̀ sought to rationalize and make sense of a traumatic event from his childhood. For al-Biqāìi, the only way he could make sense of this was to interpret his life within a symbolic and eschatological framework that gave meaning to the attack on his family by emphasizing the greatness of the miracles and kindness that was bestowed upon him and by asserting that he would, with divine favor, triumph over those trials and tribulations that afflicted him. The dream symbolism emphasizes that the attack on his family was the beginning of a series of coherent events that led to his emigration to Cairo and then his appointment as Sultan Jaqmaq's hadith teacher. In this context, the recounting of his lineage takes on new meaning because it highlights how humble his origins were. All of this serves not only to justify his position within the Cairene intellectual elite but also to make his rise to membership of the intellectual elite all the more impressive. 


\section{Bibliography}

\section{Manuscripts}

Aligarh, Maulana Azad Library, Ms ‘Arabiyya akhbār 40.

Istanbul, Köprülü Kütüphanesi, Ms Köprülü 1119.

\section{Primary Sources}

Abū Dāwūd, Sunan AbīDāwūed, eds. S. al-Arna'ūṭ and M.K. Qara Balilī, 7 vols., Damascus 2009 .

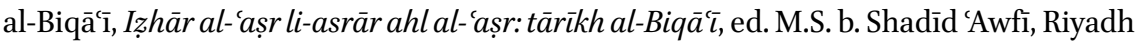
1992.

al-Biqā̄ī, 'Unwān al-zamān bi-tarājim al-shuyūkh wa-l-aqrān, ed. Ḥ. Ḥabashī, 5 vols., Cairo 2001.

Ibn Faḍl Allāh al-'Umarī, Masālik al-abṣār fi mamālik al-amșār, ed. K.S. al-Jubūrī, 27 vols., Beirut 2010.

Ibn Fahd, Mu'jam al-shuyūkh, ed. M. al-Zāhī, Riyadh 1982.

Ibn al-Jazarī, Ghāyat al-nihāya fı țabaqāt al-qurrā̄', ed. G. Bergstraesser, 2 vols., Beirut 2006.

Ibn Mājah, Sunan Ibn Mājah, ed. B. 'Awwad Ma'rūf, Beirut 1998.

Ibn Qāḍī Shuhba, Ṭabaqāt al-shāficiyya, ed. 'A. Khān, 4 vols., Hyderabad n.d.

al-Sakhāwī, al-Ḍaw' al-lāmi 'i-aḥl al-qarn al-tāsi`, Beirut 1966.

al-Tirmidhī, al-Jāmi` al-kabìr, ed. B. 'Awwad Ma'rūf, 6 vols., Beirut 1996.

\section{Secondary Sources}

Dār al-Kutub al-Mișriyya (ed.), Fihris al-kutub al-'Arabiyya al-mawjūda bi-al-Dār, 8 vols., Cairo 1924.

Ed., Hasab wa-Nasab, in $E I^{2}$.

Geertz, C., Thick description: Toward an interpretive theory of culture, in The interpretation of cultures: Selected essays, New York 1973, 3-30.

Guo, L., Al-Biqā'ī's chronicle: A fifteenth century learned man's reflection on his time and world, in H. Kennedy (ed.), The historiography of Islamic Egypt, c. 950-1800, Leiden 2001, 121-48.

Guo, L, Tales of a medieval Cairene harem: Domestic life in al-Biqa'i's autobiographical chronicle, in MSR 9-1, (2005), 101-21.

Homerin, T.E., From Arab poet to Muslim saint: Ibn al-Färid, his verse, and his shrine, Columbia 1994.

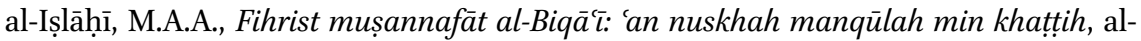
Riyāọ 2005.

Kennedy, H., From oral tradition to written record in Arabic genealogy, in Arabica 44/4 (1997), 531-44. 
Kinberg, L., Literal dreams and Prophet hadīths in classical Islam: A comparison of two ways of legitimization, in Der Islam 70/2 (1993), 279-300.

Lancaster, W., The Rwala bedouin today, Cambridge 1981.

Lawson, T., The Quran: Epic and apocalypse, London 2017.

Manșūr, 'A., Fihris makhțūtāt al-maktaba al-Ahmmadiyya bi-Tūnis: Khazanat jāmi' alZaytūna, Beirut 1969.

Neale, H.S., Jihad in premodern Sufi writings, New York 2017.

Ormsby, E.L., Theodicy in Islamic thought: The dispute Over al-Ghazālìs "Best of all possible worlds," Princeton 1984.

Reynolds, D.F. (ed.), Interpreting the self: Autobiography in the Arabic literary tradition, Berkeley 2001.

Reynolds, D.F. (ed.), Symbolic narratives of self: Dreams in medieval Arabic autobiographies, in P.F. Kennedy (ed.), On fiction and adab in medieval Arabic literature, Wiesbaden 2005, 261-86.

Saleh, W.A., A fifteenth-century Muslim Hebraist: Al-Biqāī and his defense of using the Bible to interpret the Qurān, in Speculum 83/3, (2008), 629-54.

Saleh, W.A., In defense of the Bible: A critical edition and an introduction to al-Biqā $\bar{\imath}$ 's Bible treatise (IHC 5-73), Leiden and Boston 2008.

Şeşen, R., C. İzgi and C. Akpınar, Fihris makhțūṭāt Maktabat Kūprīlī, Istanbul 1986.

Szombathy, Z., Genealogy in medieval Muslim societies, in SI 95 (2002), 5-35.

Van Steenbergen, J., Qalāwūnid discourse, elite communication and the Mamluk cultural matrix: Interpreting a 14th-century panegyric, in $J A L$ 43/1 (2012), 1-28. 